\title{
Studi Awal Pemanfaatan Lusi sebagai Bahan Bangunan dengan Tambahan Tanah Sawah, Semen dan Kapur
}

\author{
Endang Kasiati, Boedi Wibowo \\ Staf Pengajar Program Studi Diploma Teknik Sipil FTSP ITS \\ en_kas @ce.its.ac.id
}

\begin{abstract}
ABSTRAK
Mei 2006, bangsa Indonesia digemparkan dengan luapan lumpur yang bercampur dengan gas alam yang berasal dari lubang galian PT. Lapindo Brantas. Luapan lumpur yang terus menerus menimbulkan ide untuk memanfaatkan limpahan lumpur tersebut menjadi alternatif bahan bangunan, seperti halnya yang telah dilakukan dengan limbah lumpur dari PDAM. Beberapa penelitian sebelumnya telah dilakukan, baik untuk memanfaatkan lumpur tersebut menjadi batu bata bakar, batako, paving dan sebagainya. Namun bagaimana karakteristik lumpur sebenarnya jika dijadikan sebagai bahan bangunan, ini adalah inti dari penelitian berikut ini. Sebagai study awal dari pemanfaatan lumpur Sidoarjo sebagai bahan bangunan, digunakan campuran Lumpur Sidoarjo (Lusi) dengan tambahan Tanah Sawah, Semen dan pada akhirnya digunakan kapur sebagai bahan pengganti semen yang nantinya akan dibentuk benda uj i mortar. Komposisi yang digunakan adalah 40\%,50\%,55\% dan 60\% Lusi dengan variasi 3\% 6\% dan 9\% PC yang nantinya akan divariasi lagi dengan pengurangan semen terhadap kapur. Setelah dicetak, maka mortar akan diuji dalam usia 7, 14, dan 28 hari setelah dilakukan rendaman di dalam air. Dari hasil uji tekan didapatkan kuat tekan maksimal sebesar $46,7 \mathrm{~kg} / \mathrm{cm}^{2}$ yaitu dari komposisi $60 \%$ lumpur $31 \%$ tanah sawah dan $9 \%$ semen. Berdasarkan hasil tersebut maka dapat arahkan menjadi bahan bangunan semisal untuk bata beton berlubang Mutu HB $35\left(35 \mathrm{~kg} / \mathrm{cm}^{2}\right)$, batu bata kelas $25\left(25 \mathrm{~kg} / \mathrm{cm}^{2}\right)$ dan genteng.
\end{abstract}

Kata Kunci: Lusi, mortar, tanah sawah, PC, Kapur, Kuat Tekan, Bahan Bangunan, Resapan

\section{PENDAHULUAN}

Bencana Lumpur Sidoarjo, atau yang juga disebut Lumpur Lapindo, adalah bencana nasional yang telah mengakibatkan banyak kerugian di berbagai pihak. Bukan hanya pada PT. Lapindo Brantas, tetapi juga pada rakyat yang rumahnya terendam kumpur yang bercampur gas alam tersebut. Bencana ini sudah menjadi bencana nasional, bukan hanya menguras uang negara, namun juga menyebabkan goncangnya keadaan politik di Indonesia. Demonstrasi yang dilakukan oleh para penghuni perumahan TAS, menyebabkan perseteruan yang melibatkan beberapa ormas tertentu. Pemerintah sendiri bukannya tinggal diam melihat bencana tersebut, mulai dari pembentukan Timnas penanggulangan lumpur (yang hingga kini belum menuai hasil), sampai ke perundingan-perundingan antara pihak-pihak yang berseteru. Namun Lumpur yang dihasilkan oleh bencana tersebut, bukan tidak mungkin untuk dimanfaatkan.
Dalam ilmu Teknik Sipil sendiri, lumpur bukanlah material bahan bangunan yang baru. Hanya saja ada beberapa kandungan yang dimiliki oleh lumpur sidoarjo, yang membuatnya berbeda dari lumpur-lumpur lainnya. Meski secara kasat mata dan garis besar, kandungan dan fungsinya hampir sama. Berangkat dari pemikiran itulah kami melakukan penelitian yang bertujuan untuk menentukan komposisi dan fungsi yang paling mengena apabila lumpur sidoarjo itu diaplikasikan sebagai bahan bangunan alternatif. Penelitian ini sendiri masih sebagai study awal dari pemanfaatan lumpur sidoarjo tersebut. Memang ada beberapa penelitian yang langsung memfokuskan pada pengaplikasian lumpur sebagai produk jadi seperti bata, batako dan paving. Namun kebanyakan dari penelitian itu belum memberikan hasil yang memuaskan. Diharapkan study awal ini mampu memberikan solusi mengenai efisiensi dan fungsi optimal dari penggunaan lumpur 


\section{ISSN.1907-753X}

sidoarjo sebagai alternatif bahan bangunan.

\section{TINJ AUAN PUSTAKA}

Penelitian yang menjadi referensi penelitian ini antara lain:

"Evaluasi Kuat Tekan dan Resapan Mortar dari Lumpur PDAM Karang Pilang Sebagai Study Awal Batu Bata non-bakar" oleh Arya Nurakumala, 2007. [2] Pada penelitian tersebut menunjukkan kemiripan karakteristik kandungan kimia antara bahan lumpur yang digunakan dengan lumpur sidoarjo. Dan nilai kuat tekan optimal didapat dari kadar lumpur 50-70\% lumpur. Dalam penelitian ini juga digunakan bahan campuran tanah dan semen serta kapur sebagai zat pengikat.

\section{METODOLOGI PENELITIAN}

Lumpur Sidoarjo (Lusi) adalah lumpur panas PT. Lapindo yang meluber dan menggenangi lebih dari 500 hektar lahan di kawasan Kecamatan Porong. Bentuk dan sifat fisiknya adalah berwarna abu-abu, cenderung mengeras dalam keadaan kering. Supaya lebih jelas Lusi ini dapat dipakai untuk bahan bangunan apa saja maka perlu diteliti dengan bagan alir sebagai berikut:

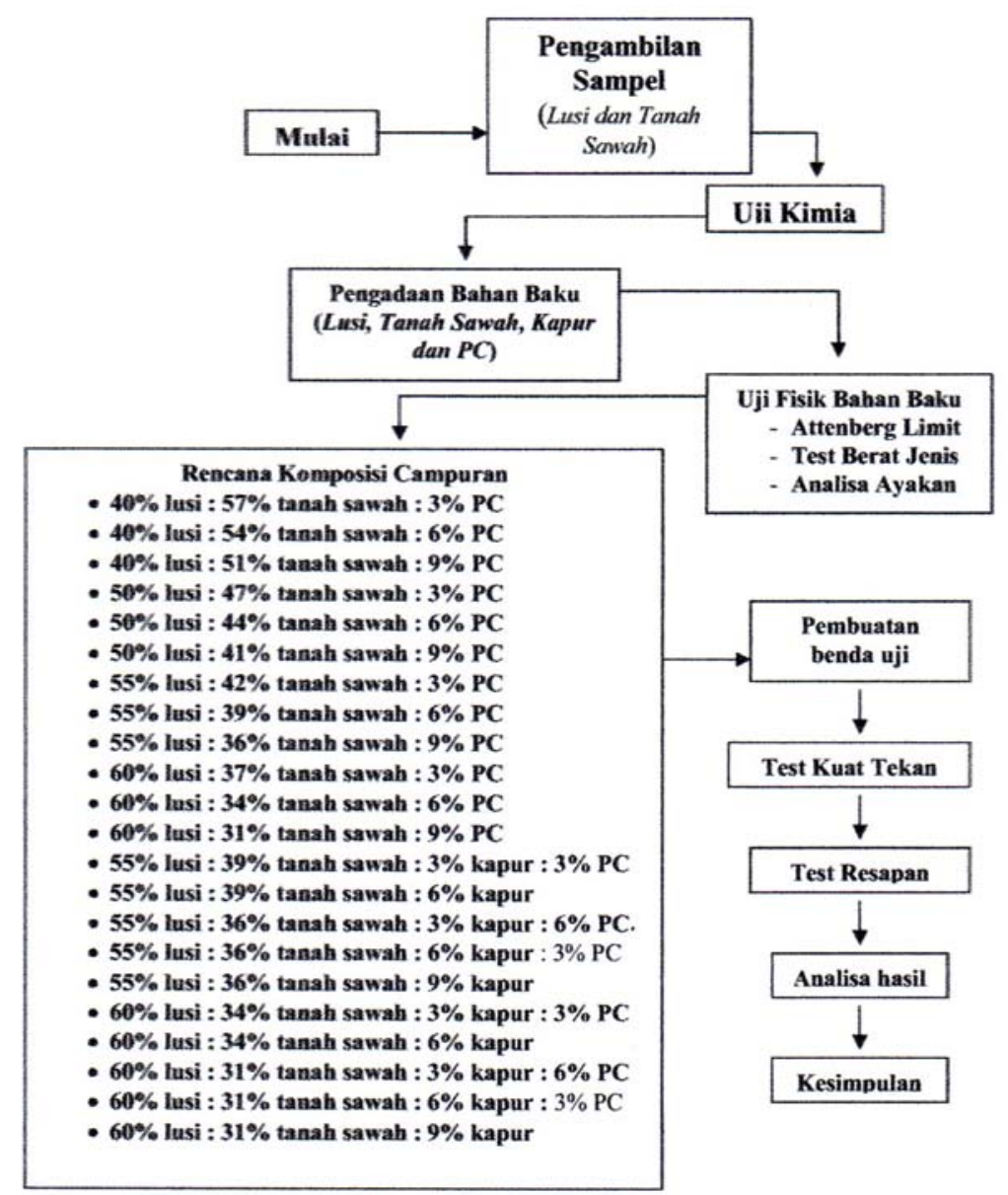

Gambar 1. Bagan Alir Pemanfaatan LUSI 
Kandungan kimia lumpur Sidoarjo (lusi) adalah sebagai berikut :

Tabel 1. Kandungan Kimia Lumpur Sidoarjo (lusi)

\begin{tabular}{|l|l|l|}
\hline No. & \multicolumn{1}{|c|}{ Kandungan Kimia } & \multicolumn{1}{|c|}{$\%$} \\
\hline 1. & $\mathrm{CaO}$ & 22,25 \\
\hline 2. & $\mathrm{MgO}$ & 5,10 \\
\hline 3. & $\mathrm{Fe} 2 \mathrm{O} 3$ & 5,85 \\
\hline 4. & $\mathrm{Al} 2 \mathrm{O} 3$ & 16,80 \\
\hline 5. & $\mathrm{SiO} 2$ & 26,31 \\
\hline 6. & Air & 22,16 \\
\hline
\end{tabular}

(Sumber : Balai Penelitian dan Konsultasi Industri, Lab Penelitian dan Konsultasi Industri Surabaya - J awa Timur)

\section{PENGAMBILAN SAMPEL}

Pengambilan beberapa sampel berupa lumpur Sidoarjo di pusat semburan lumpur di Sidoarjo dan tanah sawah di daerah Mojotamping. Penyediaan bahan baku yang dipakai untuk campuran a.l:

a. Semen Gresik Tipe I yang ada di pasaran Surabaya

b. Kapur yang ada di pasaran Surabaya

c. Pasir yang dipakai adalah pasir dari Mojokerto dan Lamongan (sebagai pembanding).

\section{PEMBUATAN BENDA UJ I}

Benda uji mortar dibuat berdasarkan SNI 0285-80. [3]. dan SNI 03-00349-1989 [5] Pembuatan benda uji mortar dilakukan secara manual menggunakan tangan. Pembuatan benda uji mortar dilakukan di laboratorium uji beton D III Teknik Sipil ITS kampus Manyar.

\section{PENGUJ IAN MATERIAL SECARA FISIK}

Pengujian secara fisik dilakukan pada material yang telah disebutkan diatas sesuai dengan SII[3].Pengujian yang dilakukan adalah sebagai berikut:

a. Test Attenberg Limit

b. Berat jenis

c. Analisa saringan

Pengujian secara fisik terhadap limbah dilakukan di laboratorium uji beton D III Teknik Sipil ITS - kampus Manyar.

\section{PERENCANAAN KOMPOSISI CAMPURAN}

Dalam penelitian ini, kami mencoba mencari komposisi antara lusi, tanah sawah, PC serta penambahan kapur sehingga sehingga menghasilkan benda uji mortar dengan efektivitas dan kualitas yang optimum. Setelah itu dilakukan percobaan untuk mengetahui hasil komposisi campuran yang telah direncanakan dan diklasifikasikan menurut mutu yang telah disyaratkan dalam SNI 03-0691-1996 [6].

Batas - batas Atterberg sangat berguna untuk identifikasi dan klasifikasi tanah.

Batas - batas ini sering digunakan secara langsung dalam spesifikasi, guna mengontrol tanah yang digunakan untuk struktur urugan tanah. Batas cair dan batas plastis tidak langsung memberi angka - angka yang dapat dipakai dalam perhitungan perencanaan. Yang kita peroleh dari percobaan Atterberg ini adalah suatu gambaran secara garis besar sifat - sifat tanah yang bersangkutan. Tanah yang batas cairnya tinggi biasanya mempunyai sifat teknik yang buruk yaitu daya dukungnya rendah, pemampatannya tinggi dan sulit memadatkannya.

\section{PEMERIKSAAN BERAT J ENIS}

Berat jenis semen adalah perbandingan antara berat butir semen dengan volume butir semen, dimana butir semen sama dengan berat minyak tanah dikalikan dengan berat jenis minyak tanah. Pemeriksaan Berat Jenis dilakukan sesuai SNI 15-25311991 [7]. Berikut ini adalah hasil pemeriksaan Berat J enis :

Tabel 2. Hasil Pemeriksaan Berat J enis

\begin{tabular}{|l|l|c|}
\hline No. & \multicolumn{1}{|c|}{ Macam Bahan } & Berat J enis \\
\hline 1. & PC & 3,1 \\
\hline 2. & Lusi & 2,48 \\
\hline 3. & Tanah Sawah & 2,27 \\
\hline & & \\
\hline
\end{tabular}

Dari hasil pemeriksaan berat jenis Lusi lebih besar dari Tanah Sawah dan Lebih kecil dari PC,yang berarti Lusi tidak dapat menggantikan PC. 
J urnal APLIKASI

Volume 8, Nomor 2, Agustus 2010

ISSN.1907-753X

PENGUJ IAN ANALISA AYAKAN

Tabel 3. Hasil Pengujian Analisa Ayakan

\begin{tabular}{|l|l|c|}
\hline No. & \multicolumn{1}{|c|}{ Macam bahan } & Zona \\
\hline 1 & Pasir Lamongan & 2 \\
\hline 2 & Pasir Mojokerto & 3 \\
\hline 3 & Lusi & 2 \\
\hline 4 & Tanah Sawah & 2 \\
\hline 5 & $40 \%$ Lusi $+60 \%$ tanah sawah & 2 \\
\hline 6 & $50 \%$ Lusi $+50 \%$ tanah sawah & 2 \\
\hline 7 & $55 \%$ Lusi $+45 \%$ tanah sawah & 2 \\
\hline 8 & $60 \%$ Lusi $+40 \%$ tanah sawah & 2 \\
\hline
\end{tabular}

Dari pemeriksaan analisa ayakan Lusi masuk zone 2 begitu pula campuran Lusi dan tanah sawah yang berarti bisa menggantikan Pasir.

\section{PENGUJ IAN BATAS-BATAS ATTERBERG}

Tabel 4. Hasil Pemeriksaan Batas-Batas Atterberg

\begin{tabular}{|c|l|c|c|c|c|}
\hline No & \multicolumn{1}{|c|}{ CAMPURAN } & $\begin{array}{c}\mathrm{LL} \\
(\%)\end{array}$ & $\begin{array}{c}\mathrm{PL} \\
(\%)\end{array}$ & $\begin{array}{c}\mathrm{SL} \\
(\%)\end{array}$ & $\begin{array}{c}\mathrm{TP} \\
(\%)\end{array}$ \\
\hline 1 & $\begin{array}{l}40 \text { \% Lusi-60\% } \\
\text { tanah sawah }\end{array}$ & 61,62 & 33,02 & 52,97 & 28,60 \\
\hline 2 & $\begin{array}{l}50 \% \text { Lusi }+50 \% \\
\text { tanah sawah }\end{array}$ & 65,29 & 28,88 & 42,18 & 36,41 \\
\hline 3 & $\begin{array}{l}55 \% \text { Lusi }+45 \% \\
\text { tanah sawah }\end{array}$ & 66,40 & 27,06 & 34,36 & 39,34 \\
\hline 4 & $\begin{array}{l}60 \% \text { Lusi }+40 \% \\
\text { tanah sawah }\end{array}$ & 68,36 & 25,68 & 21,37 & 42,68 \\
\hline
\end{tabular}

Dari hasil pemeriksaan batas-batas Atterberg IP pada campuran no.1 adalah yang mendekati $25 \%$ yaitu batas kekuatan tanah yang tinggi, yang berarti percobaan ini dapat dilanjutkan untuk pemeriksaan kekuatan tekan sesuai SNI 03-6825-2002 [9].

\section{Grafik 1. Perbandingan Lusi \& Tanah Sawah Terhadap Semen Umur 7 Hari}

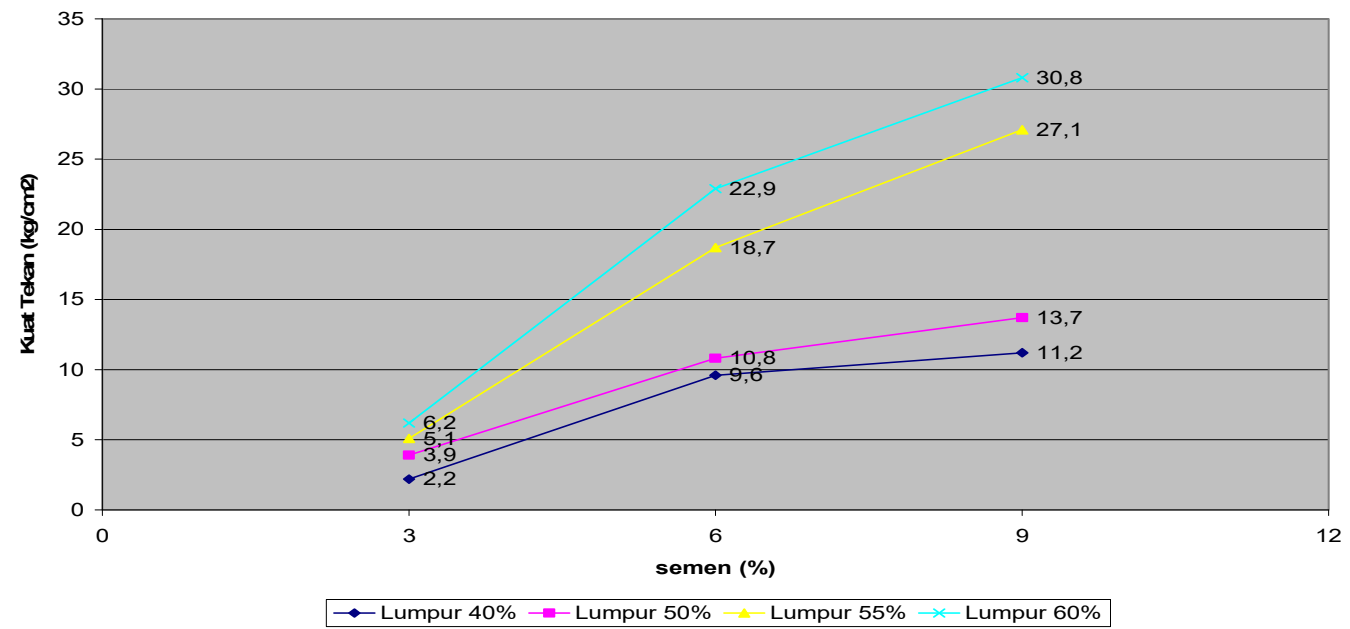

J urnal APLIKASI: Media Informasi \& Komunikasi Aplikasi Teknik Sipil Terkini 
Grafik 2.Perbandingan Lusi \& Tanah Sawah Terhadap Semen Umur 14 Hari

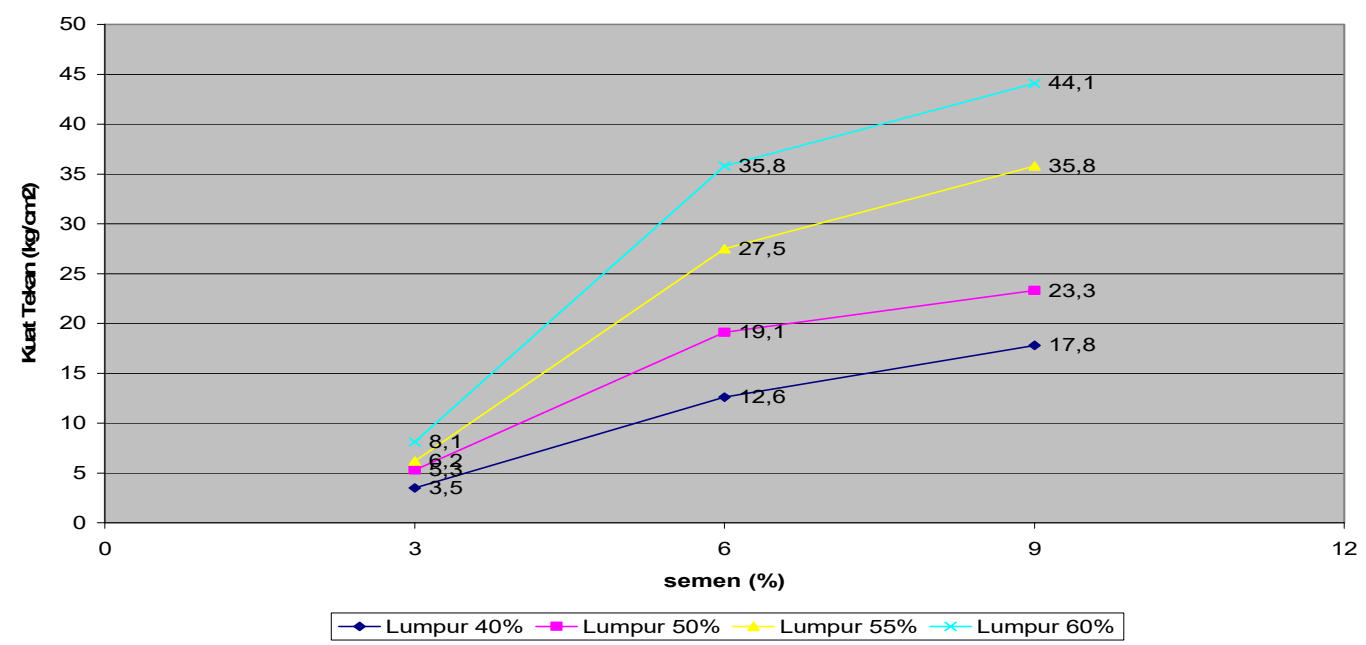

Grafik 3.Perbandingan Lusi \& Tanah Sawah Terhadap Semen Umur 28 Hari

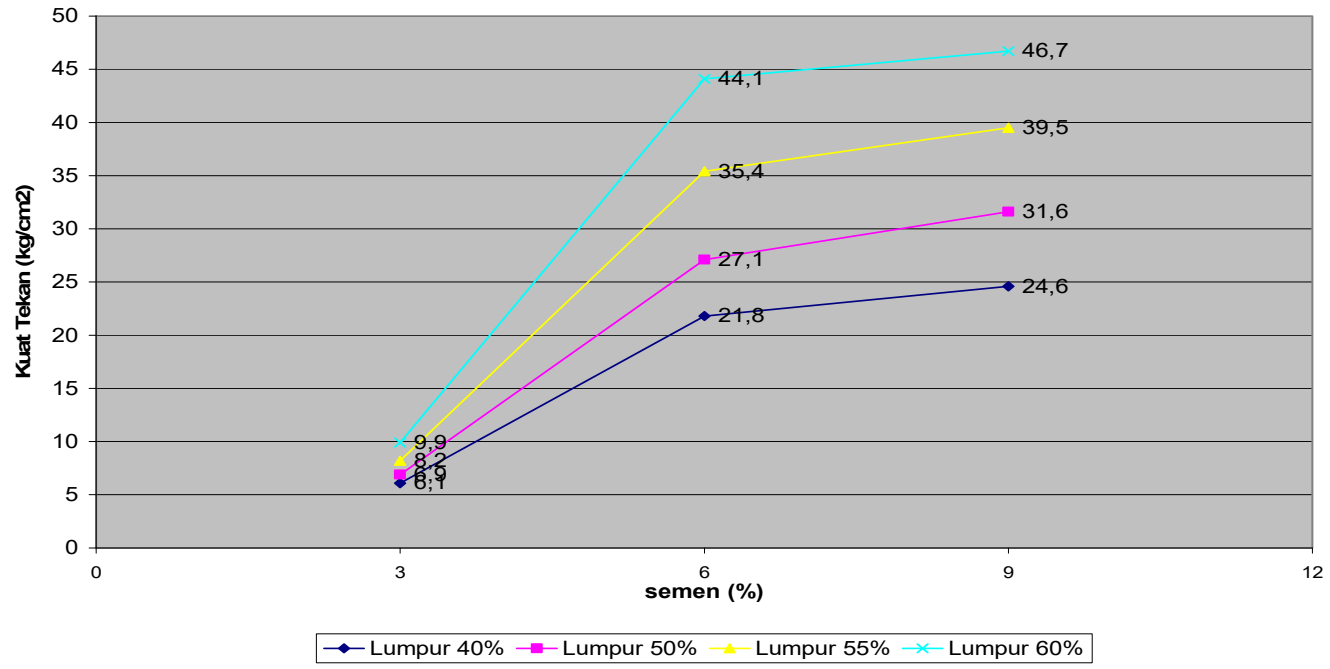

Halaman 52 J urnal APLIKASI: Media Informasi \& Komunikasi Aplikasi Teknik Sipil Terkini 


\section{Grafik 4. Daya Serap Perbandingan Lusi \& Tanah Sawah Terhadap Semen}

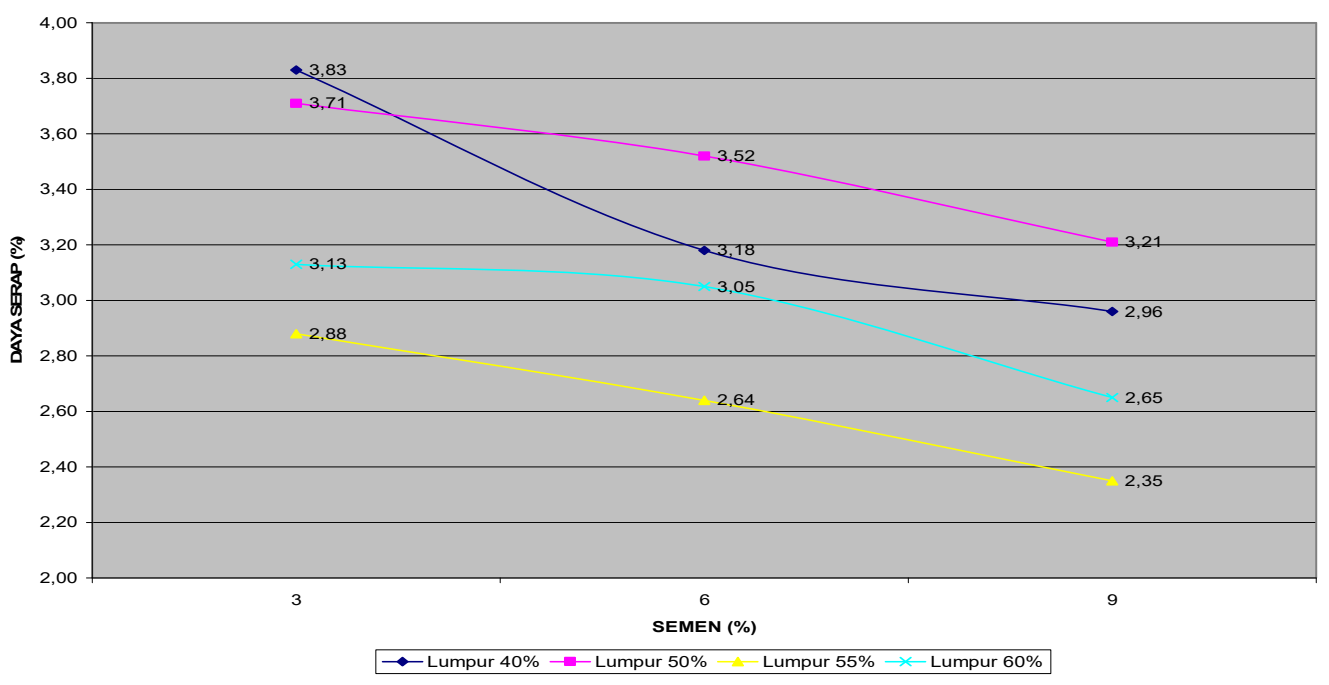

Grafik 5. Daya Serap Perbandingan Lusi \& Tanah Sawah Terhadap Kapur \& Semen

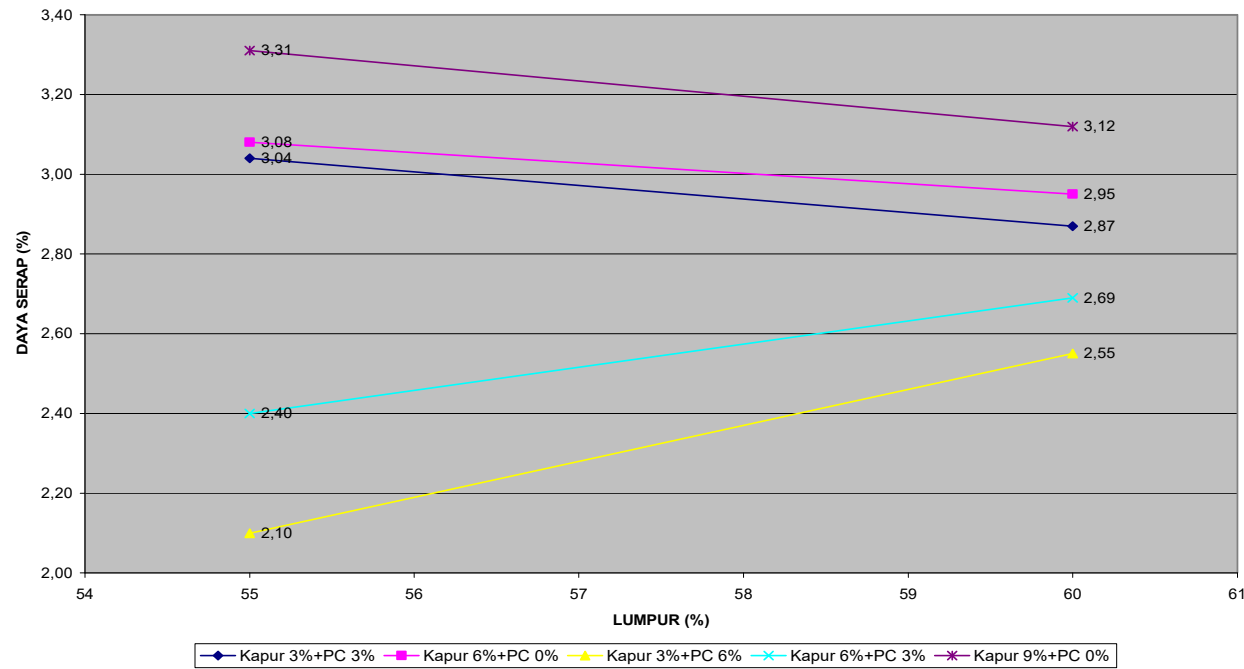


Grafik 6. Perbandingan Lusi \& Tanah Sawah Terhadap Kapur \& Semen Umur 7 Hari

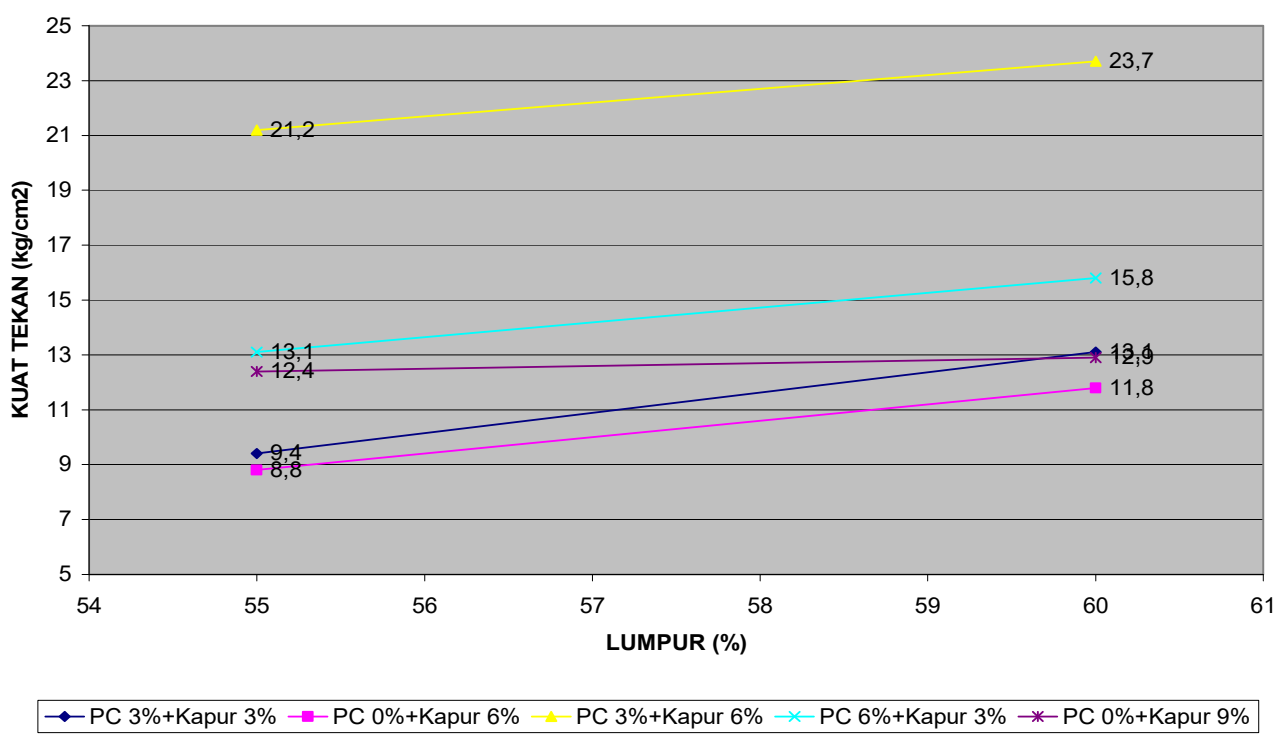

Grafik 7. Perbandingan Lusi \& Tanah Sawah Terhadap Kapur \& Semen Umur 14 Hari

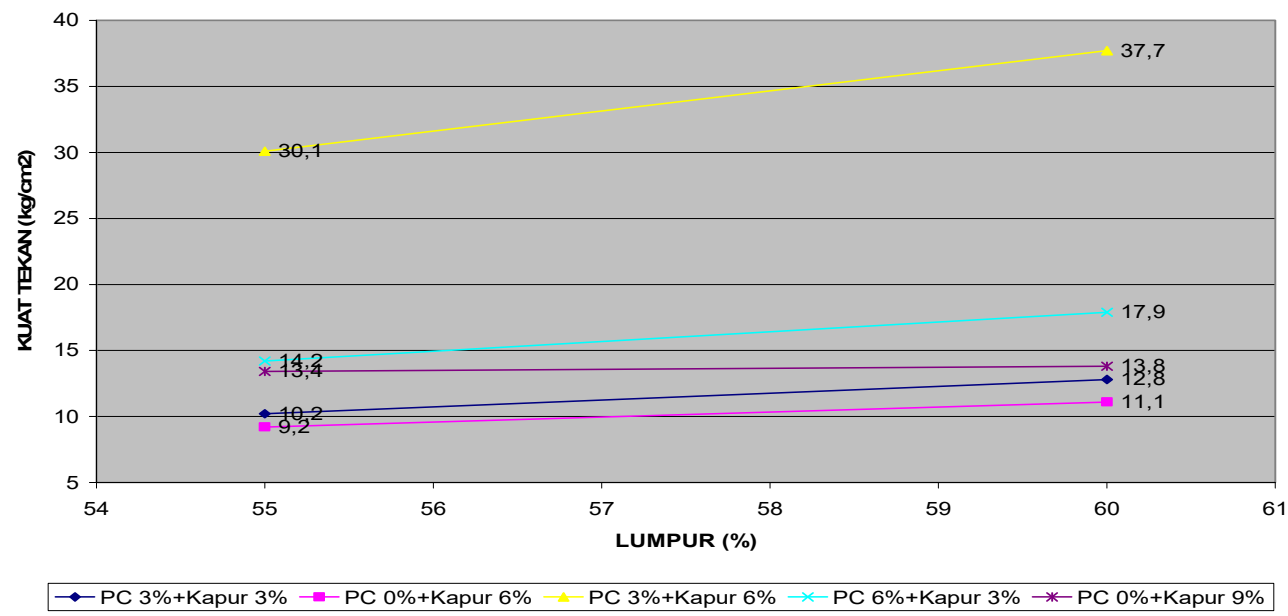

Halaman 54 J urnal APLIKASI: Media Informasi \& Komunikasi Aplikasi Teknik Sipil Terkini 


\section{Grafik 8. Perbandingan Lusi \& Tanah Sawah Terhadap Kapur \& Semen Umur 28 Hari}

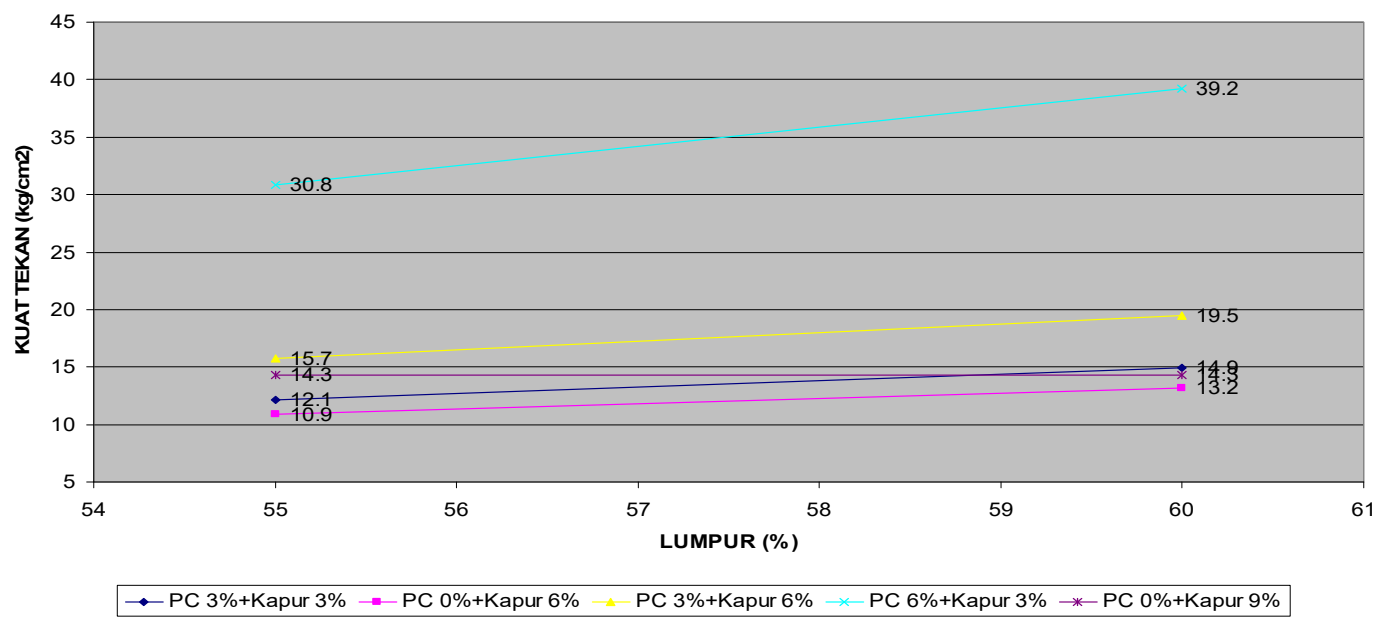

Analisa Grafik :

1. Nilai Kuat Tekan tertinggi didapat pada komposisi $60 \%$ Lusi, 31\% Tanah Sawah, 6\% PC dan 3\% Kapur yaitu $39,2 \mathrm{~kg} / \mathrm{cm}^{2}$.

2. Nilai Kuat Tekan terendah didapat pada komposisi $55 \%$ Lusi, 39\% Tanah Sawah, dan $6 \%$ Kapur yaitu sebesar $10,9 \mathrm{~kg} / \mathrm{cm}^{2}$.

3. Semakin besar persentase kapur dalam campuran semakin kecil kuat tekannya, hal ini berbanding terbalik dengan persentase PC dimana semakin besar persentase PC maka semakin besar nilai kuat tekannya.

4. Komposisi campuran $40 \%$ Lusi, $57 \%$ Tanah Sawah, 3\% Semen mempunyai daya serap paling tinggi yaitu 3,83 \%

5. Pada campuran $55 \%$ Lusi, $36 \%$ Tanah Sawah, 9\% Semen mempunyai daya serap paling rendah yaitu 2,35\%

6. Semakin besar variabel variasi semen maka prosentase daya serap semakin meningkat.
7. Dengan penambahan kapur, komposisi campuran 55\% Lusi, 36\% Tanah Sawah dan 9\% Kapur mempunyai daya serap paling tinggi yaitu 3, $31 \%$

8. Campuran 55\% Lusi, 36\% Tanah Sawah, 3\% Kapur dan 6\% Semen mempunyai daya serap paling rendah yaitu $2,21 \%$

\section{KESIMPULAN}

Berdasarkan hasil penelitian diatas maka dapat diambil kesimpulan sebagai berikut :

1. Nilai kuat tekan maksimal dicapai pada komposisi 60\% Lusi, 31\% Tanah Sawah dan 9\% PC yaitu sebesar 46,7 $\mathrm{kg} / \mathrm{cm} 2$ dengan nilai resapan sebesar $2,65 \%$

2. Nilai resapan minimal dicapai pada komposisi 55\% Lusi, 39\% Tanah Sawah, 6\% PC dan 3\% Kapur, yaitu sebesar 2,21 \% dengan nilai kuat tekan $30,8 \mathrm{~kg} / \mathrm{cm} 2$.

Dari hasil nilai kuat tekan dan resapan yang dicapai maka campuran Lusi, Tanah Sawah, Semen dan Kapur dapat diarahkan 
sebagai material alternatif untuk Bata Beton Berlubang, genteng mutu rendah dan paving mutu rendah.

\section{DAFTAR PUSTAKA}

[1] Debby, Sari, Optimasi Pemanfaatan Abu Ampas Tebu Sebagai Bahan Tambahan Batu Bata dengan Campuran Tanah Sawah dan Limbah Lumpur Instalasi Pengolahan Air Minum (IPAM) dengan Pembakaran 1100oc, 2005.

[2] Nurakumala Arya, Evaluasi Kuat Tekan dan Resapan Mortar dari Lumpur PDAM Karangpilang sebagai Study Awal Batu Bata Non Bakar, 2007.

[3] Standar Industri Indonesia (SII) 028580, Mutu dan cara uji Bata Beton Berlubang Departemen Perindustrian Republik Indonesia, 1980.

[4] Standar Nasional Indonesia (SNI) 030096-1995, Mutu dan Cara Uji Genteng Beton, Departemen Perindustrian Republik Indonesia, 1995.
[5] Standar Nasional Indonesia (SNI) 030349-1989, Bata Beton untuk Pasangan Dinding, Departemen Perindustrian Republik Indonesia, 1989.

[6] Standar Nasional Indonesia (SNI) 030691-1996, Bata Beton untuk Lantai (Paving Block), Departemen

Perindustrian Republik Indonesia, 1996.

[7] Standar Nasional Indonesia (SNI) 152531-1991, Metode Pengujian Berat J enis Semen Portland, Departemen Perindustrian Republik Indonesia, 1991.

[8] Standar Nasional Indonesia (SNI) 150302-1999, Semen Portland Pozolan, Departemen Perindustrian Republik Indonesia, 1999.

[9] Standar Nasional Indonesia (SNI) 036825-2002, Metode Pengujian Kekuatan Tekan Mortar Semen Portland Untuk Pekerjaan Sipil, Departemen Perindustrian Republik Indonesia, 2002. 